\title{
Restoring Nitric Oxide Cytosolic Calcium Regulation by Cyclic Guanosine Monophosphate Protein Kinase I Alpha Transfection in Coronary Endothelial Cells of Spontaneously Hypertensive Rats
}

\author{
Silvia Nistri ${ }^{a}$ Lorenzo Di Cesare Mannelli ${ }^{b}$ Luca Mazzettib ${ }^{b}$ Robert Feil ${ }^{c}$ \\ Daniele Bani $^{a}$ Paola Failli ${ }^{b}$ \\ Departments of a Anatomy, Histology and Forensic Medicine and ${ }^{\mathrm{b}}$ Pharmacology, University of Florence, \\ Florence, Italy; ${ }^{C}$ Interfakultäres Institut für Biochemie Signaltransduktion - Transgene Modelle, University of \\ Tübingen, Tübingen, Germany
}

\section{Key Words}

Angiotensin II - Cytosolic intracellular calcium concentration - Microcoronary endothelial cells •

Wistar Kyoto rats

\begin{abstract}
In microcoronary endothelial cells (RCEs) from spontaneously hypertensive rats (SHR), the nitric oxide (NO)/cyclic guanosine monophosphate (GMP)-dependent proteinkinase I (cGKI) pathway cannot regulate the cytosolic calcium $\left(\left[\mathrm{Ca}^{2+}\right]_{\mathrm{i}}\right)$ dynamic as in RCEs from Wistar Kyoto rats (WKY). We investigated the altered downstream NO target in SHR cells and, since cGKI expression was low, whether the re-expression of cGKI $\alpha$ in SHR RCEs could restore NO calcium responsiveness. We measured $\left[\mathrm{Ca}^{2+}\right]_{i}$ dynamic by fura- 2 imaging analysis and the cGKI level by RT-PCR and Western blot in SHR and WKY RCEs. Plasmids encoding for enhanced green fluorescence protein or CGKI $\alpha$-enhanced green fluorescence protein were transiently transfected in SHR RCEs, and $\left[\mathrm{Ca}^{2+}\right]_{i}$ was evaluated. Angiotensin-II (AT-II) increased $\left[\mathrm{Ca}^{2+}\right]_{\mathrm{i}}$ in a concentrationdependent way in both strains. Whereas in WKY, endogenously produced NO and cyclic GMP analog decreased the
\end{abstract}

AT-II-induced $\left[\mathrm{Ca}^{2+}\right]_{i}$ transient, they were ineffective in SHR RCEs. The cGKI level was low in SHR cells. However, after cGKl $\alpha$ re-expression, endogenous NO decreased the AT-IIinduced $\left[\mathrm{Ca}^{2+}\right]_{i}$ transient, while endothelial NO synthase and cGKI inhibition prevented it. The low expression of cGKI in SHR accounts for the absent regulation of the agonist-induced $\left[\mathrm{Ca}^{2+}\right]_{\mathrm{i}}$ transient by the NO/cyclic GMP pathway. Studies on CGKI in humans could contribute to a better understanding of cardiovascular pathologies.

Copyright $\odot 2012$ S. Karger AG, Basel

\section{Introduction}

Endothelial cells accomplish a well-defined regulatory role in the maintenance of blood pressure homeostasis, platelet aggregation and vascular remodeling. Endothelial dysfunctions are involved in elevated blood pressure, atherosclerosis and thrombosis. Many endothelium-derived substances are involved in this delicate homeostat-

\section{S.N., L.D.C.M. and L.M. contributed equally to this research.}

\section{KARGER \\ Fax +4161306 1234 \\ E-Mail karger@karger.ch}

www.karger.com
(C) 2012 S. Karger AG, Basel

$1018-1172 / 12 / 0493-0221 \$ 38.00 / 0$

Accessible online at:

www.karger.com/jvr
Dr. Paola Failli

Department of Pharmacology, University of Florence

Viale Pieraccini, 6

IT-50139 Florence (Italy)

Tel. +39 055427 1241, E-Mail paola.failli@ unifi.it 
ic regulation; in particular, nitric oxide (NO) is a vascular smooth muscle relaxant agent and platelet aggregation inhibitor. In the endothelium, $\mathrm{NO}$ is mainly produced by NO synthase [NOS type III, endothelial NOS (eNOS)], that can be activated by several agonists in a calciumdependent mode [1]. Among other agonists, angiotensin II (AT-II), through the activation of its type 1 receptors (AT1), can activate eNOS in isolated rat aortic [2] and microcoronary endothelial cells [3].

Many NO actions are achieved by different mechanisms that include the regulation of cytosolic intracellular calcium concentration $\left(\left[\mathrm{Ca}^{2+}\right]_{\mathrm{i}}\right)$ dynamics. The activation of soluble guanylyl cyclase/cyclic guanosine monophosphate (GMP)/cyclic GMP-dependent protein kinase type I (cGKI) is involved in this effect. The cGKI is a serine/threonine kinase able to phosphorylate many intracellular proteins, including calcium regulator proteins [4].

Indeed, early research in this field demonstrates that in Chinese hamster ovary cells transfected with a plasmid-encoding $\alpha$ isoform of cGKI (cGKI $\alpha)$, the $\left[\mathrm{Ca}^{2+}\right]_{\mathrm{i}}$ transient induced by thrombin is suppressed when the enzyme is activated by a cyclic GMP analog, this effect being dependent on the decreased production of inositol 1,4,5-trisphosphate [5]. In line with the effectiveness of cGKI in reducing the $\left[\mathrm{Ca}^{2+}\right]_{\mathrm{i}}$ transient induced by agonists, cGKI knock-out mice have altered the homeostatic control of blood pressure (hypertension) as well as increased platelet aggregation [6].

Other reports show that vascular smooth muscle cells isolated from cGKI knock-out mice cannot regulate the increase in $\left[\mathrm{Ca}^{2+}\right]_{\mathrm{i}}$ induced by agonists as cells from naïve mice do [7]. Moreover, the re-expression of cGKI isoforms in smooth muscle cells of cGKI knockout mice restores NO regulation of $\left[\mathrm{Ca}^{2+}\right]_{i}[7,8]$. Similar results have been obtained in Chinese hamster ovary cells, where stable transfection of the cGKI $\alpha$ and, to a lesser extent, cGKI $\beta$ can modulate the increase in $\left[\mathrm{Ca}^{2+}\right]_{\mathrm{i}}$ induced by thrombin, while in human coronary smooth muscle cells, the silencing of cGKI $\alpha$ by RNA interference can potentiate $\left[\mathrm{Ca}^{2+}\right]_{i}$ signaling induced by the same agonist [9]. Furthermore, in aortic smooth muscle cells isolated from spontaneously hypertensive rats (SHR), we reported a low expression of cGKI and an insensitivity of the $\left[\mathrm{Ca}^{2+}\right]_{i}$ transient to NO/cyclic GMP/cGKI modulation. The reexpression of cGKI $\alpha$ re-establishes $\mathrm{NO} /$ cyclic GMP/cGKI $\left[\mathrm{Ca}^{2+}\right]_{\mathrm{i}}$ regulation $[10]$.

NO can also decrease $\left[\mathrm{Ca}^{2+}\right]_{\mathrm{i}}$ in endothelial cells and therefore regulates endothelium function [11]. In particular, the NO modulation of $\left[\mathrm{Ca}^{2+}\right]_{i}$ can reduce the activa- tion of eNOS and therefore its own production in an autocrine/paracrine mode. This negative feedback mechanism is believed to protect cells from the detrimental effect of excessive NO production $[1,11]$.

In microcoronary endothelial cells (RCEs) isolated from the heart of normotensive Wistar Kyoto (WKY) rats, NO (exogenously administered as NO donor) and atrial natriuretic peptide (that increases intracellular cyclic GMP by activating its guanylyl cyclase receptor) decreases the $\left[\mathrm{Ca}^{2+}\right]_{\mathrm{i}}$ transient induced by thrombin and bradykinin [12]. Also, the endogenously produced NO controls the $\left[\mathrm{Ca}^{2+}\right]_{i}$ transient in WKY RCEs since eNOS inhibitors destroy this regulation.

On the other hand, in RCEs from SHR, $\left[\mathrm{Ca}^{2+}\right]_{\mathrm{i}}$ is insensitive to NO-mediated regulation. The lack of NO responsiveness in RCEs isolated from SHR is also observed when phosphodiesterases are inhibited and intracellular cyclic GMP is increased by atrial natriuretic factor [12]. Therefore, a downstream defective mechanism of this regulatory pathway could account for the alteration in $\left[\mathrm{Ca}^{2+}\right]_{\mathrm{i}}$ handling in SHR cells. On the other hand, cGKI activity and protein expression are reduced in whole heart homogenates [13] and cardiomyocytes [14] isolated from SHR. Therefore, we aimed to explore cGKI in more detail in RCEs and to test if its re-expression in SHR cells could restore NO $\left[\mathrm{Ca}^{2+}\right]_{\mathrm{i}}$ responsiveness. As AT-II plays an important role in hypertension, we decided to use this agonist to induce the $\left[\mathrm{Ca}^{2+}\right]_{\mathrm{i}}$ increase in RCEs, since the presence of AT-II receptors in RCEs and its effectiveness in inducing NO production has already been described [3].

Some of these data were presented at the Fourth International Conference on Relaxin and Related Peptide [15].

\section{Materials and Methods}

\section{Animals}

All animal manipulations were carried out according to the European Community guidelines for animal care (DL 116/92, application of the European Communities Council Directive $86 / 609 / \mathrm{EEC}$ ). The ethical policy of the University of Florence conforms with the Guide for the Care and Use of Laboratory Animals of the US National Institutes of Health (NIH Publication No. 8523, revised 1996; University of Florence assurance number: A5278-01). Formal approval to conduct the experiments described was obtained from the Animal Subjects Review Board of the University of Florence. For all experiments described herein, 12 - to 14 -week-old male normotensive WKY $(310.5 \pm 6.95 \mathrm{~g})$ and age-matched SHR $(311.7 \pm 9.26$ g) were used (Charles River, Italy). Four rats were housed per cage (size $26 \times 41 \mathrm{~cm}$ ); animals were fed with standard laboratory diet and tap water ad libitum and kept at $23 \pm 1{ }^{\circ} \mathrm{C}$ with a 12-hour light/dark cycle, light at 
7 a.m. Animals were anesthetized before sacrifice by cervical dislocation and hearts were isolated as described [12]. No differences between WKY and SHR heart/body ratios were measured, as previously described [16].

\section{Isolation and Culture of Rat Coronary Endothelial Cells}

Hearts were digested with $0.1 \%$ collagenase in Krebs-Henseleit solution; the obtained cell suspension was treated with trypsin $\left(0.05 \%\right.$ in phosphate-buffered saline for $30 \mathrm{~min}$ at $\left.37^{\circ} \mathrm{C}\right)$ and plated in culture flasks for $4 \mathrm{~h}$ in complete RCE medium (M-199 containing $10 \%$ fetal bovine serum and $10 \%$ newborn calf serum, 250 $\mathrm{IU} \mathrm{ml} \mathrm{m}^{-1}$ penicillin $\mathrm{G}$ and $250 \mu \mathrm{g} \mathrm{ml}^{-1}$ streptomycin). Then, nonadherent cells were removed by washing and adherent endothelial cells were grown until confluence. The obtained cells were characterized as previously described $[12,17]$ by their positive uptake of acetylated low-density lipoproteins (1,1'-dioctadecyl3,3,3',3'-tetramethyl-indocarbocyanine perchlorate complex; Biochemical Technologies Inc., Stoughton, Mass., USA). For all experiments, cells were used at the first passage in culture. Twenty-eight different cell lines (10 from WKY and 18 from SHR) were used for these experiments.

\section{Cytosolic Intracellular Calcium Determination}

$\left[\mathrm{Ca}^{2+}\right]_{\mathrm{i}}$ was measured using a ratiometric image analysis system [12]. Confluent cells grown on glass coverslips were loaded with $4 \mu \mathrm{M}$ fura-2 AM (Molecular Probes-Invitrogen Life Technologies, San Giuliano Milanese, Italy) for $45 \mathrm{~min}$ at room temperature. Coverslips were mounted in a perfusion chamber and placed on the stage of an epifluorescence microscope (TMD Diaphot, Nikon Co., Tokyo, Japan) equipped with a 75-watt Xenon lamp, an automated filter exchanger (carrying four filters centered at 340, 380, 410 and $490 \mathrm{~nm}$ ) and a changeable dichroic filter block. For $\left[\mathrm{Ca}^{2+}\right]_{\mathrm{i}}$ determination, two excitation wavelengths (340 and $380 \mathrm{~nm}$ ), a 400-nm dichroic mirror (DM 400) and a $510 \mathrm{~nm}$ barrier filter (BA 510) were used. Video images were obtained with an extended ISIS-M camera (Photonic Science, Robertsbridge, UK). Ten to 15 cells were analyzed in each microscopic field. Followingin-time images obtained at 340 and $380 \mathrm{~nm}$ excitation, emission $510 \mathrm{~nm}$, were digitalized by an analogical/digital converter and rationed on a pixel-by-pixel basis. Ratio images were obtained every $1.2 \mathrm{~s}$ and calibrated using ionomycin and EGTA ( $\mathrm{pH}$ 7.8) [12]. A dissociation constant of $224 \mathrm{nM}$ for fura-2 was used to obtain nanomolar $\left[\mathrm{Ca}^{2+}\right]_{\mathrm{i}}$ quantification $[18]$. Decay time and $\left[\mathrm{Ca}^{2+}\right]_{\mathrm{i}}$ increase $\left(\Delta\left[\mathrm{Ca}^{2+}\right]_{\mathrm{i}}\right)$ were calculated for each single cell [12] and parameter means were used for further statistical evaluations.

\section{Reverse Transcription PCR for cGKI mRNA}

The mRNA level for cGKI was assayed by reverse transcription PCR (RT-PCR) in WKY and SHR RCEs and in SHR cells transfected with cytomegalovirus immediate early promoter fused with enhanced green fluorescent protein plasmid (pCMV-EGFP) or pCMV-cGKI $\alpha$-EGFP (whole-cell culture extract; see below for plasmid transfection). $500 \mathrm{ng}$ of total RNA was reverse transcribed and amplified with SuperScript ${ }^{\mathrm{TM}}$ One-Step ${ }^{\mathrm{TM}}$ RT-PCR System (Invitrogen Life Technologies), as previously described [10]. The following rat gene specific primers were used: cGKI mRNA (NM_001105731), forward 5'-CACATTGTGGACACGAGACA-3' and reverse 5'-GCAAACGCTTCTACCACACA-3'; $\beta$-actin mRNA (NM_031144), forward 5'-CCAACCGTGAAAAGATGACC-3' and reverse 5'-AGAGGTCTTTACGGATG-
TCA-3'. The expected length of the amplified fragments was 233 and $539 \mathrm{bp}$ for cGKI and $\beta$-actin, respectively. Densitometric analysis was conducted by measuring the bands as well as the smear of each lane by means of Scion Image analysis software. $\beta$-Actin normalization was performed for each result.

\section{Western Blot for Soluble Guanylyl Cyclase and cGKI}

Confluent RCEs were lysed in cold buffer (Tris/HCl, $\mathrm{pH}$ 7.4, $10 \mathrm{mM}, \mathrm{NaCl} 10 \mathrm{~mm}, \mathrm{MgCl}_{2} 1.5 \mathrm{~mm}, \mathrm{Na}_{2}$ EDTA $2 \mathrm{mM}$, phenylmethylsulfonyl fluoride, $1 \mathrm{mM}$, Triton X-100 1\%, leupeptin $20 \mu \mathrm{g} /$ $\mathrm{ml}$, pepstatin $1 \mu \mathrm{g} / \mathrm{ml}$, Pefabloc ${ }^{\circledR} 1 \mathrm{mg} / \mathrm{ml}$, aprotinin $2.5 \mu \mathrm{g} / \mathrm{ml}$ ) and centrifuged. Freshly isolated ventricles from SHR and WKY hearts were immediately frozen in liquid nitrogen, homogenized in cold lysis buffer, and the obtained suspension was centrifuged. Seventy-five micrograms of supernatant proteins were electrophoresed by SDS-PAGE (7.6\% polyacrylamide), blotted onto nitrocellulose membranes (Amersham, Cologno Monzese, Italy) and handed as described [8] using rabbit polyclonal anti-cGKI antibodies (1:300; Calbiochem, San Diego, Calif., USA) followed by peroxidase-labeled goat anti-rabbit antibodies (1:10,000; Vector, Burlingame, Calif., USA). For soluble guanylyl cyclase immunoblot, chicken polyclonal anti-soluble guanylyl cyclase $\left(\alpha_{1}-\beta_{1}\right.$ heterodimer) antibodies (1:500; Enzo Life Sciences, Lausen, Switzerland) and peroxidase-labeled rabbit anti-chicken antibodies $(1: 150,000)$ were used. Membranes were also immunostained with rabbit polyclonal anti- $\beta$-actin antibodies $(1: 20,000)$. Immune reaction was revealed using enhanced chemiluminescence (Amersham). Densitometric analysis was conducted by measuring the bands of each lane by means of the Scion Image analysis software. $\beta$-Actin normalization was performed for each result.

\section{Transient Transfection of cGKI $\alpha$ Isoform Plasmid}

The pCMV-cGKI $\alpha$-EGFP vector was engineered to obtain a construct encoding cGKI $\alpha$ as a fusion to the N-terminus of EGFP [7]. pCMV-EGFP encoded EGFP (Clontech-Celbio, Pero Milanese, Italy) only. These mammalian expression plasmids confer kanamycin resistance and contain a CMV immediate early promoter. pCMV-cGKI $\alpha$-EGFP and pCMV-EGFP were transformed in a DH5 $\alpha$ competent Escherichia coli strain (Novagen-Merck, Darmstadt, Germany). A single colony from a plate was used to inoculate $250 \mathrm{ml}$ of Luria-Bertani medium containing $30 \mu \mathrm{g} / \mathrm{ml}$ kanamycin, and the culture was incubated for $16 \mathrm{~h}$ at $37^{\circ} \mathrm{C}$. Bacteria were collected by centrifugation at $4^{\circ} \mathrm{C}$ for $15 \mathrm{~min}$ at 6,000 g. Amplified plasmid DNA was purified by QIAfilter Plasmid MaxiPrep (Qiagen, Milan, Italy). The fusion protein possesses enzymatic activity similar to the native form [7].

The described expression plasmids encoding cGKI $\alpha$-EGFP protein or EGFP alone were transfected in semiconfluent RCEs from SHR using Lipofectamine ${ }^{\mathrm{TM}}$ (Invitrogen Life Technologies) in a ratio of $6 \mu \mathrm{g}$ DNA:151 $\mu \mathrm{g}$ lipofectamine, and cells were grown for an additional $72 \mathrm{~h}$. Cells were loaded with fura-2, and $\left[\mathrm{Ca}^{2+}\right]_{\mathrm{i}}$ was measured as described in the previous paragraph. In each optical field examined for $\left[\mathrm{Ca}^{2+}\right]_{\mathrm{i}}$ measurement, we identified cells expressing plasmids (positive cells) by looking at their EGFP fluorescence using an excitation wavelength of $490 \mathrm{~nm}$, emission of $510 \mathrm{~nm}$ and a dichroic mirror at $500 \mathrm{~nm}$. No interferences between fura-2 and EGFP fluorescence were detected.

Unless otherwise specified, all reagents were purchased from Sigma-Aldrich (Milan, Italy) and were of the highest analytical grade. 


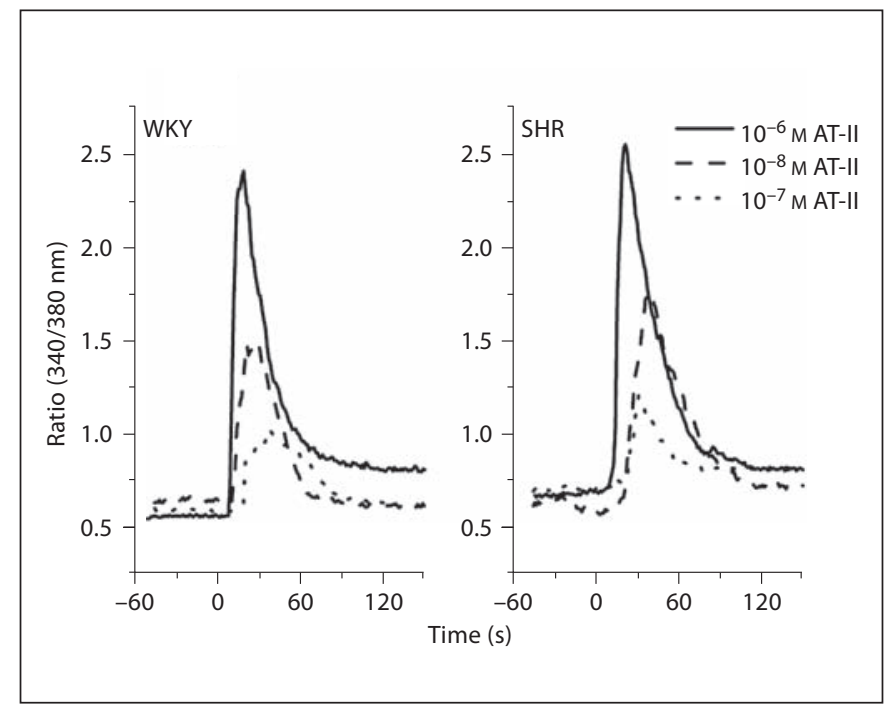

Fig. 1. Concentration-dependent effect of AT-II on $\left[\mathrm{Ca}^{2+}\right]_{\mathrm{i}}$ in RCEs isolated from WKY and SHR. Typical time course of AT-II$\left(10^{-8}\right.$ to $\left.10^{-6} \mathrm{M}\right)$ induced calcium transient in WKY and SHR RCEs. AT-II was administered at time 0 . Traces are the mean of at least 10 cell recordings. $\left[\mathrm{Ca}^{2+}\right]_{\mathrm{i}}$ was measured using fura-2 fluorescence applied to a ratiometric image analysis system. For more details, see Materials and Methods.

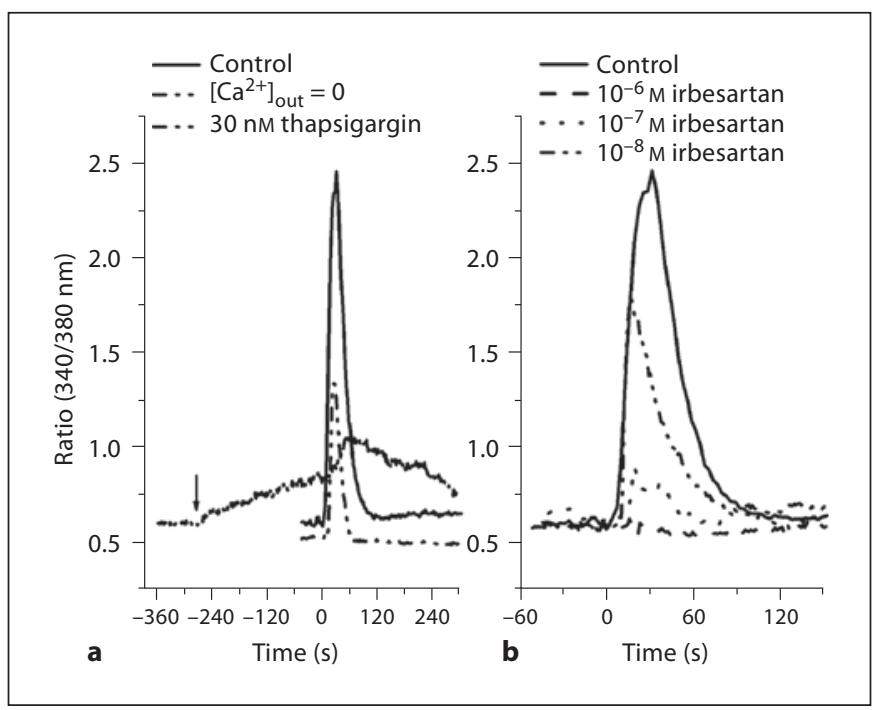

Fig. 2. Characterization of AT-II signal in rat RCEs. Typical time course of $10^{-6} \mathrm{M}$ AT-II signal in WKY RCEs. AT-II was administered at time 0 . a AT-II was administered in control conditions, extracellular calcium-free medium $\left(\left[\mathrm{Ca}^{2+}\right]_{\text {out }}=0\right)$ or in the presence of $30 \mathrm{nM}$ thapsigargin (administered at the arrow). b AT-II was administered in control conditions or in the presence of $10^{-6}$ to $10^{-8} \mathrm{M}$ irbesartan. Irbesartan was preincubated for $10 \mathrm{~min}$ before AT-II. Traces are the mean of at least 10 cell recordings. $\left[\mathrm{Ca}^{2+}\right]_{i}$ was measured using fura-2 fluorescence applied to a ratiometric image analysis system. For more details, see Materials and Methods.
Statistical Analysis

Data are reported as means $\pm S E M ; n$ indicates the number of different cell lines analyzed. Statistical analysis was performed using one-way ANOVA followed by the Student-Newman-Keuls test. A p value $\leq 0.05$ was considered as significant.

\section{Results}

\section{Effect of AT-II in WKY and SHR RCEs}

In basal conditions, $\left[\mathrm{Ca}^{2+}\right]_{\mathrm{i}}$ was $119.5 \pm 5.76(\mathrm{n}=10)$ and $137.1 \pm 7.42 \mathrm{nM}(\mathrm{n}=16)$ in WKY and SHR cells, respectively. As previously described in RCEs isolated from Wistar rats [19], AT-II concentration-dependently induced a transient increase in $\left[\mathrm{Ca}^{2+}\right]_{\mathrm{i}}$ in RCEs from WKY and SHR (fig. 1). In the absence of extracellular calcium, this $\left[\mathrm{Ca}^{2+}\right]_{\mathrm{i}}$ transient was reduced, while after incubation with thapsigargin, the $\left[\mathrm{Ca}^{2+}\right]_{i}$ signal was practically absent (fig. 2a). The effect of AT-II was prevented by incubating cells with $10^{-8}$ to $10^{-6} \mathrm{M}$ irbesartan (fig. $2 \mathrm{~b}$ ), suggesting that AT-II increased $\left[\mathrm{Ca}^{2+}\right]_{\mathrm{i}}$ in RCEs by activating its type 1 receptor. A similar pathway of $\left[\mathrm{Ca}^{2+}\right]_{\mathrm{i}}$ signaling was found in SHR cells (data not shown).

By comparing the AT-II-induced $\left[\mathrm{Ca}^{2+}\right]_{\mathrm{i}}$ signaling in WKY and SHR cells, we revealed that the $\left[\mathrm{Ca}^{2+}\right]_{\mathrm{i}}$ transient was characterized by a slightly higher peak in RCEs from SHR (fig. 3a, b) followed by a much slower decline to baseline, as demonstrated by the significant enhancement of the decay time as compared to WKY cells (fig. 3a, c). In RCEs from WKY, the rapid decline in the AT-II-induced $\left[\mathrm{Ca}^{2+}\right]_{\mathrm{i}}$ transient was significantly slowed by incubation with the specific NOS inhibitor L-NAME $\left(\mathrm{N}^{\omega}\right.$-nitro-Larginine methyl ester $\mathrm{HCl} ; 10^{-4} \mathrm{M}, 10 \mathrm{~min}, 37^{\circ} \mathrm{C}$; fig. $3 \mathrm{c}$ ). Of note, NOS inhibition did not change the $\left[\mathrm{Ca}^{2+}\right]_{\mathrm{i}}$ transient in RCEs from SHR (fig. 3c), and in this experimental condition, no significant differences between WKY and SHR cells were observed. Similar behavior was also observed when WKY cells were pretreated with the cGKI inhibitor KT-5823 $\left(10^{-6} \mathrm{M}, 10 \mathrm{~min}, 37^{\circ} \mathrm{C}\right)$ before administration of AT-II. KT-5823 increased the decay time in WKY, but did not modify it in SHR cells. Conversely, pretreatment with the membrane-permeable cyclic GMP analog DBC ( $\mathrm{N}^{2}, 2^{\prime}$-O-dibutyrylguanosine $3^{\prime}, 5^{\prime}$-cyclic monophosphate sodium salt; $10^{-6} \mathrm{M}, 10 \mathrm{~min}, 37^{\circ} \mathrm{C}$ ) significantly reduced the $\left[\mathrm{Ca}^{2+}\right]_{\mathrm{i}}$ transient peak and decay time in WKY; being ineffective in SHR cells to a lesser extent, the NO donor S-nitroso-N-acetylpenicillamine (SNAP) slightly reduced both the $\left[\mathrm{Ca}^{2+}\right]_{\mathrm{i}}$ transient peak and decay time in WKY (not significant) and was completely ineffective in SHR cells (fig. 3b, c). Since the influ- 


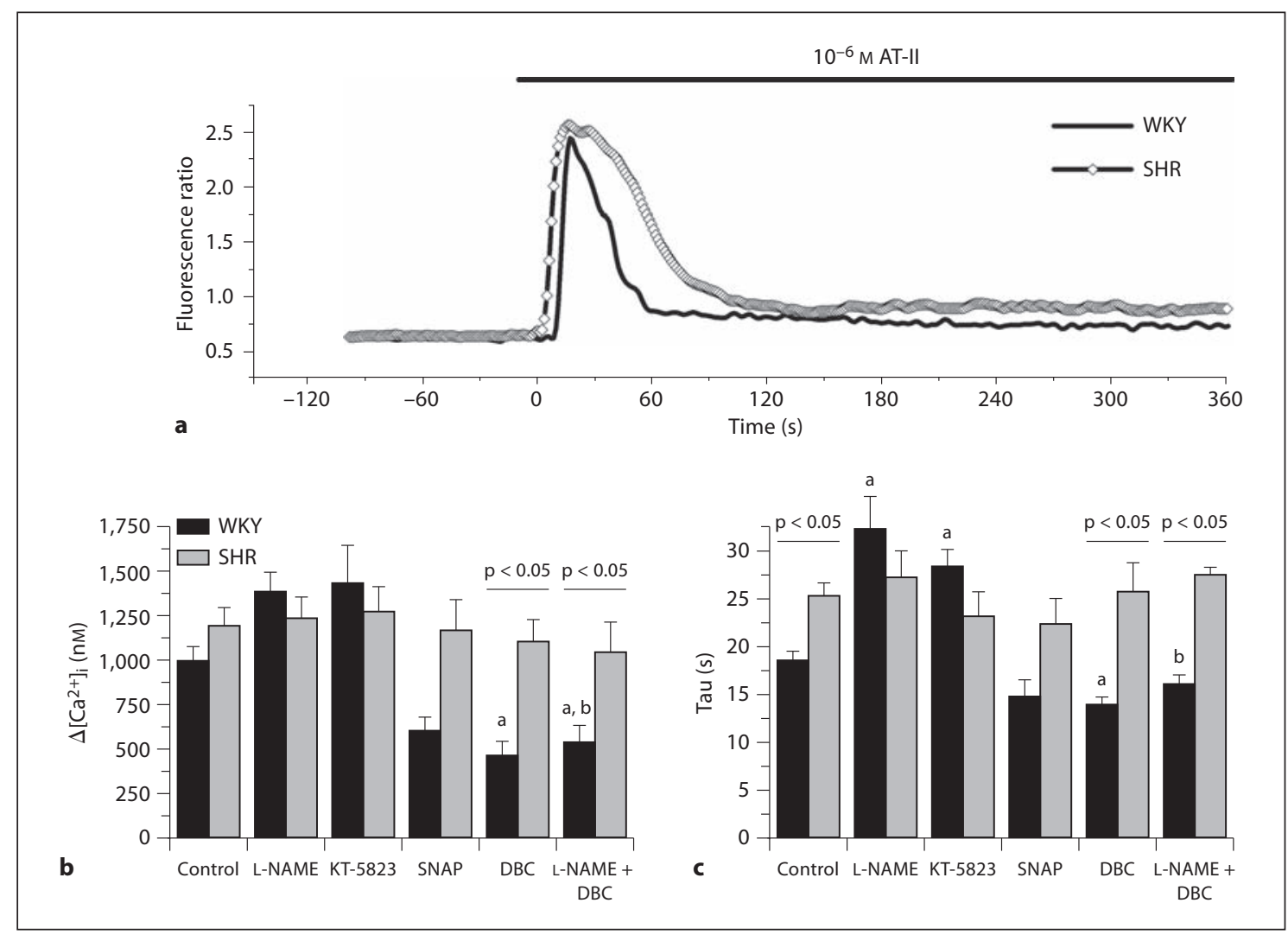

Fig. 3. Effect of AT-II on $\left[\mathrm{Ca}^{2+}\right]_{i}$ in RCEs isolated from WKY and SHR. a Typical time course of $10^{-6}$ M AT-II-induced calcium transient in WKY and SHR RCEs. AT-II was administered at time 0. Traces are the mean of at least 10 cell recordings. $\left[\mathrm{Ca}^{2+}\right]_{\mathrm{i}}$ was measured using fura-2 fluorescence applied to a ratiometric image analysis system. For more details, see Materials and Methods. b $\left[\mathrm{Ca}^{2+}\right]_{\mathrm{i}}$ increase induced by $10^{-6} \mathrm{M}$ AT-II. $\Delta\left[\mathrm{Ca}^{2+}\right]_{\mathrm{i}}$ (nM concentration) was obtained as the difference between the maximal and basal $\left[\mathrm{Ca}^{2+}\right]_{\mathrm{i}}$ values. $\mathbf{c}$ Decay time of the calcium transient induced by $10^{-6} \mathrm{M}$ AT-II. Decay time ('tau' $\tau$ of monoexponential fitting) was calculated for each single cell according to the following equation: $\mathrm{Y}=\mathrm{y}_{0}+\mathrm{A} \cdot \mathrm{e}^{(-\mathrm{x} \cdot \tau)}$ and expressed in seconds. Columns represent means \pm SEM of at least 10 different cell preparations where at least 10 cells were analyzed for each experiment. $10^{-4} \mathrm{M}$ L-NAME, $10^{-6} \mathrm{M} \mathrm{KT}-5823,10^{-6} \mathrm{M}$ DBC and $10^{-4} \mathrm{M}$ SNAP were incubated for $10 \mathrm{~min}$ at $37^{\circ} \mathrm{C}$ before the administration of AT-II. ${ }^{\mathrm{a}} \mathrm{p}<0.05$ versus control, same strain; ${ }^{\mathrm{b}} \mathrm{p}<0.05$ versus L-NAME, same strain. Differences between strains are indicated by bars (one-way ANOVA, followed by Student-Newman-Keuls test). ence of self-produced endogenous $\mathrm{NO}$ could potentiate the effectiveness of DBC, we performed experiments in which DBC was coincubated with the eNOS inhibitor LNAME. When WKY cells were contemporaneously incubated with L-NAME and DBC, both $\left[\mathrm{Ca}^{2+}\right]_{\mathrm{i}}$ transient peak and decay time were decreased as compare to $\mathrm{L}^{-}$ NAME alone. All these results showed that NO/cyclic GMP/cGKI pathway modified the AT-II-induced $\left[\mathrm{Ca}^{2+}\right]_{\mathrm{i}}$ transient in WKY, whereas it was ineffective in SHR RCEs (fig. 3b, c).

\section{cGKI Level in RCEs}

As shown by RT-PCR, the mRNA for cGKI was lower in SHR than in WKY (fig. 4a). Densitometric analy- sis showed that the mRNA level was significantly reduced in SHR RCEs (fig. 4b). Similar results were obtained by monitoring cGKI protein by Western blot analysis (fig. 5a). As shown by the densitometric analysis (fig. 5b), the enzyme was significantly less expressed in SHR as compared to WKY cells. Also, in freshly isolated heart ventricles, cGKI expression was significantly lower in SHR than in WKY (fig. 5). On the other hand, soluble guanylyl cyclase in RCEs of WKY and SHR was not differently expressed as measured by densitometric analysis of Western blot $(4.3 \pm 0.45$ and $4.8 \pm 0.37$ arbitrary units in WKY and SHR, respectively; $\mathrm{n}=4$ ). 


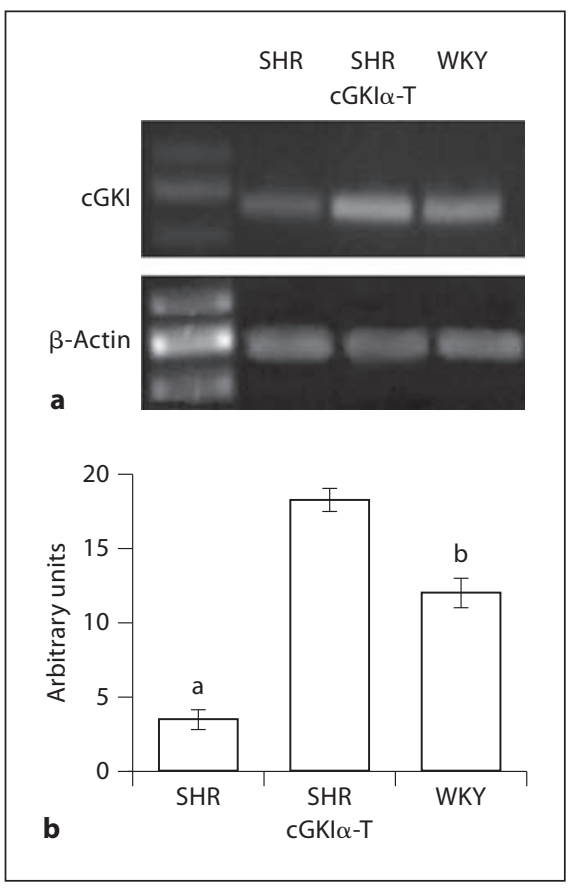

Fig. 4. mRNA level of cGKI in WKY and SHR RCEs. a mRNA level for cGKI was assayed by RT-PCR in both naïve (SHR), cGKI $\alpha$-transfected SHR (SHR cGKI $\alpha-T$ ) and naïve WKY RCEs. The first gel lane shows molecular weight markers. b Densitometric analysis (means \pm SEM) of the mRNA level of 4 separate RCE experiments. $\beta$-Actin normalization was performed for each result. ${ }^{a} \mathrm{p}<0.05$ versus other groups (one-way ANOVA followed by Student-Newman-Keuls test); ${ }^{\mathrm{b}} \mathrm{p}<0.05$ versus SHR cGKI $\alpha-\mathrm{T}$.

\section{Effect of cGKI $\alpha$-EGFP Transfection on $\left[\mathrm{Ca}^{2+}\right]_{i}$}

\section{Dynamics in SHR}

Consistently with these results, we transfected SHR RCEs with a plasmid encoding for cGKI $\alpha$-EGFP or EGFP alone. In the whole cell culture extract, the transfection of cGKI $\alpha$-EGFP significantly increased cGKI mRNA quantity, carrying it to a higher level than in WKY (fig. 4). As identified by their EGFP fluorescence, positive cells were $35-40 \%$ of the total cell number. A representative image of transfected cells is depicted in figure 6 .

Thereafter, $\left[\mathrm{Ca}^{2+}\right]_{i}$ was studied in cGKI $\alpha$-EGFP (cGKI $\alpha$-positive) and EGFP-positive cells. The re-expression of $\mathrm{cGKI} \alpha$ consistently modified the $\left[\mathrm{Ca}^{2+}\right]_{\mathrm{i}}$ transient induced by AT-II (fig. 7). In fact, in cGKI $\alpha$-positive cells, the $\Delta\left[\mathrm{Ca}^{2+}\right]_{\mathrm{i}}$ induced by AT-II was significantly decreased as compared to EGFP-positive (fig. 7a) and -naïve (fig. 3b) RCEs. Similarly, the decay time was significantly reduced in cGKI $\alpha$-positive RCEs (fig. 7b). Conversely, EGFP-pos- itive cells (fig. 7) behaved as naïve SHR RCEs. In order to test whether the decrease in the AT-II-induced $\left[\mathrm{Ca}^{2+}\right]_{\mathrm{i}}$ transient in cGKI $\alpha$-positive cells was dependent on the endogenous production of NO, we performed experiments in cells preincubated with the NOS inhibitor LNAME $\left(10^{-4} \mathrm{M}, 10 \mathrm{~min}, 37^{\circ} \mathrm{C}\right)$. As shown in figure 7 , in cGKI $\alpha$-positive cells, preincubation with L-NAME significantly increased $\Delta\left[\mathrm{Ca}^{2+}\right]_{\mathrm{i}}$ (fig. 7a) and decay time (fig. $7 \mathrm{~b}$ ) as compared to their cGKI $\alpha$-positive control cells, whereas both parameters remained unchanged in EGFP-positive RCEs. Similarly, preincubation with KT5823 modified the $\left[\mathrm{Ca}^{2+}\right]_{\mathrm{i}}$ transient in cGKI $\alpha$-positive RCEs but was ineffective in EGFP-positive cells. Moreover, although DBC did not significantly modify the $\left[\mathrm{Ca}^{2+}\right]_{\mathrm{i}}$ transient in cGKI $\alpha$-positive cells, it counteracted the effect of L-NAME incubation. Also, SNAP can slightly decrease the $\left[\mathrm{Ca}^{2+}\right]_{\mathrm{i}}$ transient and decay time in cGKI $\alpha$ positive cells.

\section{Discussion}

Our data demonstrate that the inadequate expression of cGKI accounts for the absent regulation of $\left[\mathrm{Ca}^{2+}\right]_{\mathrm{i}}$ by the NO/cyclic GMP/cGKI pathway in SHR RCEs. Moreover, the re-expression of cGKI $\alpha$ is sufficient to restore $\mathrm{NO} /$ cyclic GMP/cGKI control of the AT-II-induced $\left[\mathrm{Ca}^{2+}\right]_{\mathrm{i}}$ transient, thus underlying the central role of cGKI in calcium signaling.

cGKI has been less extensively studied in endothelium than in other tissues although several authors report its expression and function in primary cultures of microvascular endothelial cells $[20,21]$. Among other functions, cGKI can reduce NO production in endothelial cells by means of a negative feedback mechanism [11]. Indeed, $\mathrm{NO}$ (produced in endothelial cells by the calcium-dependent enzyme eNOS) decreases agonist-induced $\left[\mathrm{Ca}^{2+}\right]_{i}$ transients through cGKI activation. Therefore, by reducing $\left[\mathrm{Ca}^{2+}\right]_{\mathrm{i}}$, NO can modulate its own production by a negative autocrine loop [11]. This autoregulation represents an important protective mechanism from the detrimental effects of excessive $\left[\mathrm{Ca}^{2+}\right]_{i}$ and NO. Specifically, in aortic endothelial cells, AT-II can stimulate the production of NO and peroxynitrite [2]. It is well established that peroxynitrite can interact with lipids, DNA, and proteins through direct oxidative reactions or indirect, radical-mediated mechanisms and its excessive production can induce cell necrosis or apoptosis $[22,23]$.

Several authors have already described AT-II activity on endothelial cells $[2,3,19]$. As reported by Bayraktutan 
Fig. 5. cGKI protein expression in WKY and SHR RCEs and freshly isolated heart ventricles. a Protein expression for cGKI in confluent RCEs and freshly isolated ventricles. b Densitometric analysis (means \pm SEM) of cGKI protein levels of 4 different experiments. $\beta$-Actin normalization was performed for each result. ${ }^{\mathrm{a}} \mathrm{p}<0.05$ (one-way ANOVA), SHR versus WKY.
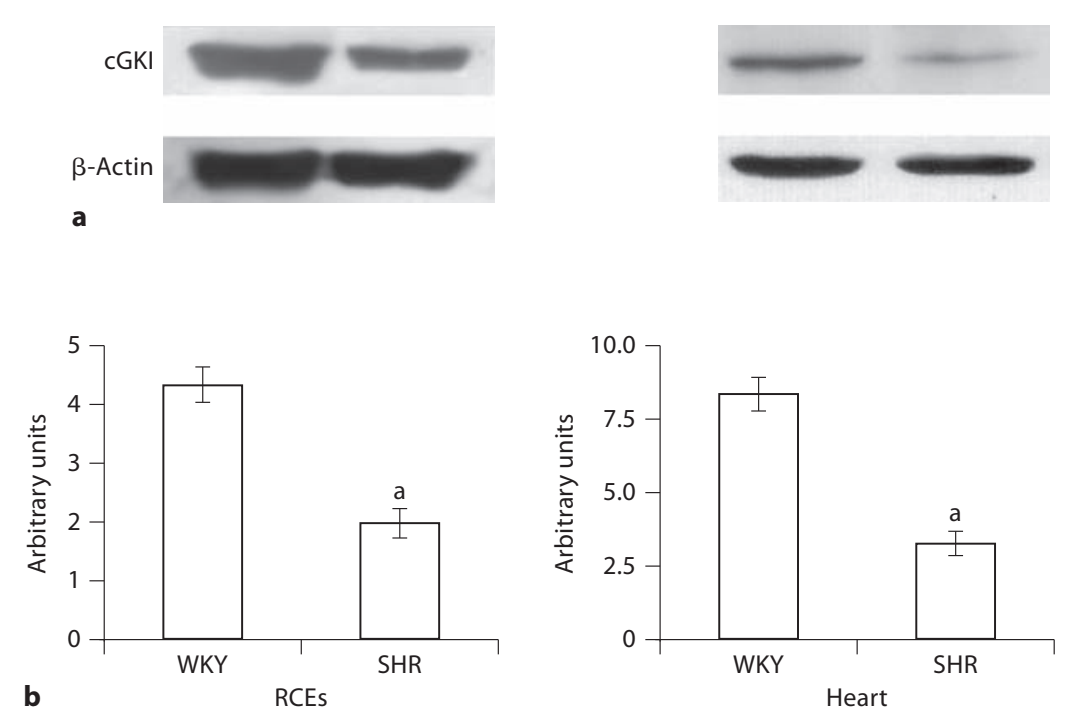

and Ulker [3], AT-II increases NO production in rat RCEs by acting through AT1 receptors as its action is prevented by valsartan. Therefore, due to its relevant role in hypertension, AT-II appears as an adequate agonist for the study of the role of the NO/cyclic GMP/cGKI pathway in SHR RCEs.

Our research shows that AT-II induces a concentration-dependent increase in $\left[\mathrm{Ca}^{2+}\right]_{\mathrm{i}}$ in both WKY and SHR RCEs. This $\left[\mathrm{Ca}^{2+}\right]_{i}$ signal is mainly dependent on the discharge of intracellular calcium stores followed by an influx from extracellular milieu. Indeed, incubation with thapsigargin strongly reduces it, while in the absence of extracellular calcium, the $\left[\mathrm{Ca}^{2+}\right]_{\mathrm{i}}$ transient is reduced but still maintained. This $\left[\mathrm{Ca}^{2+}\right]_{\mathrm{i}}$ signal characterization is in line with that already described by Nilius and Droogmans [1]. AT-II acts primarily on AT1 receptors, since it is antagonized by irbesartan in both strains. Also, the NO production as described by Bayraktutan and Ulker [3] is mainly antagonized by valsartan, demonstrating a large involvement of AT1 in this effect.

In WKY cells, AT-II-induced $\left[\mathrm{Ca}^{2+}\right]_{\mathrm{i}}$ increase is strictly regulated by the $\mathrm{NO} /$ cyclic GMP/cGKI pathway, since NOS and cGKI inhibition increases the $\left[\mathrm{Ca}^{2+}\right]_{\mathrm{i}}$ transient (mainly the decay time), while DBC and to a lesser degree SNAP decreases it. According to Kasseckert et al. [24], cGKI $\alpha$ activation can increase $\left[\mathrm{Ca}^{2+}\right]_{\mathrm{i}}$ sequestration in the endoplasmic reticulum in endothelial cells isolated from rat coronary circulation. This effect is dependent on

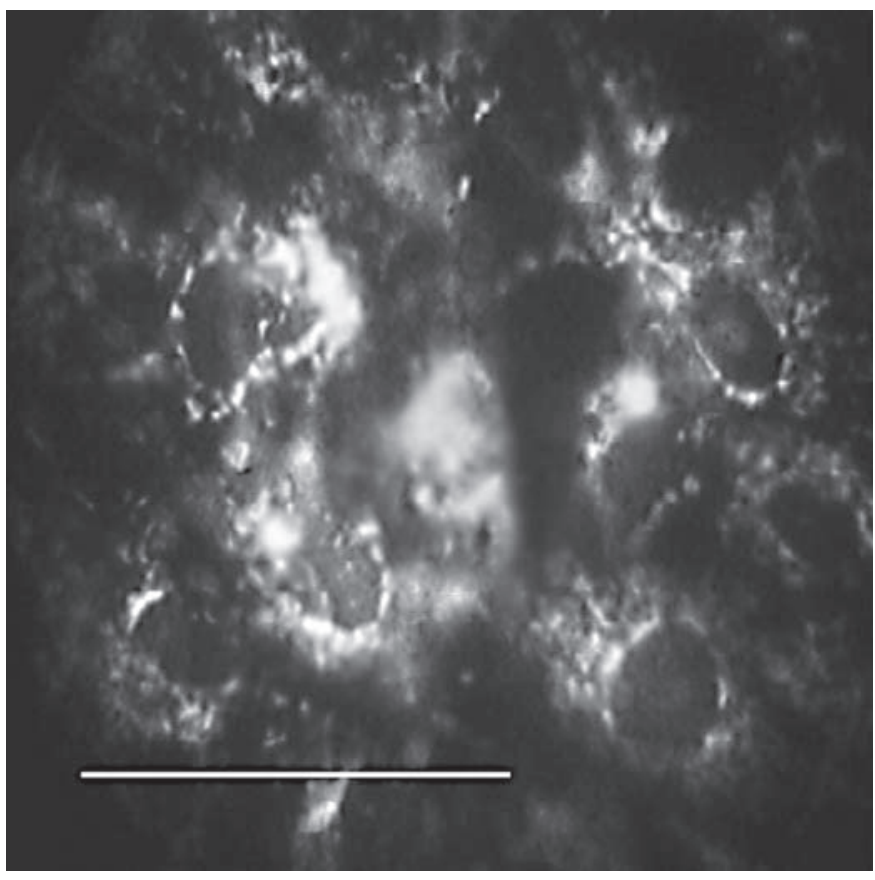

Fig. 6. Image of SHR RCEs transfected with cGKI $\alpha$-EGFP. The fluorescence of EGFP was monitored at $490 \mathrm{~nm}$ excitation and 510 $\mathrm{nm}$ emission, as described. Bar $=50 \mu \mathrm{m}$. 
Fig. 7. Effect of AT-II on $\left[\mathrm{Ca}^{2+}\right]_{\mathrm{i}}$ in SHR RCEs transfected with cGKI $\alpha$-EGFP or EGFP encoding plasmids. a $\left[\mathrm{Ca}^{2+}\right]_{\mathrm{i}}$ increase induced by $10^{-6} \mathrm{M}$ AT-II $\left(\Delta\left[\mathrm{Ca}^{2+}\right]_{\mathrm{i}}\right)$. $\Delta\left[\mathrm{Ca}^{2+}\right]_{\mathrm{i}}$ (nM concentration) was obtained as the difference between the maximal and basal $\left[\mathrm{Ca}^{2+}\right]_{\mathrm{i}}$ values. b Decay time of the calcium transient induced by $10^{-6}$ M AT-II. Decay time ('tau' $\tau$ of monoexponential fitting) was calculated for each single cell according to the following equation: $\mathrm{Y}=\mathrm{y}_{0}$ $+\mathrm{A} \cdot \mathrm{e}^{(-\mathrm{x} \cdot \tau)}$ and expressed in seconds. Columns represent means \pm SEM of results obtained in at least 6 different preparations. $10^{-4} \mathrm{M} \mathrm{L}-\mathrm{NAME}, 10^{-6} \mathrm{M}$ KT-5823, $10^{-6} \mathrm{M}$ DBC and $10^{-4} \mathrm{M}$ SNAP were incubated for $10 \mathrm{~min}$ at $37^{\circ} \mathrm{C}$ before the administration of AT-II; ${ }^{a} \mathrm{p}<0.05$ versus control. Differences between groups are indicated by bars (one-way ANOVA, followed by Student-Newman-Keuls test).
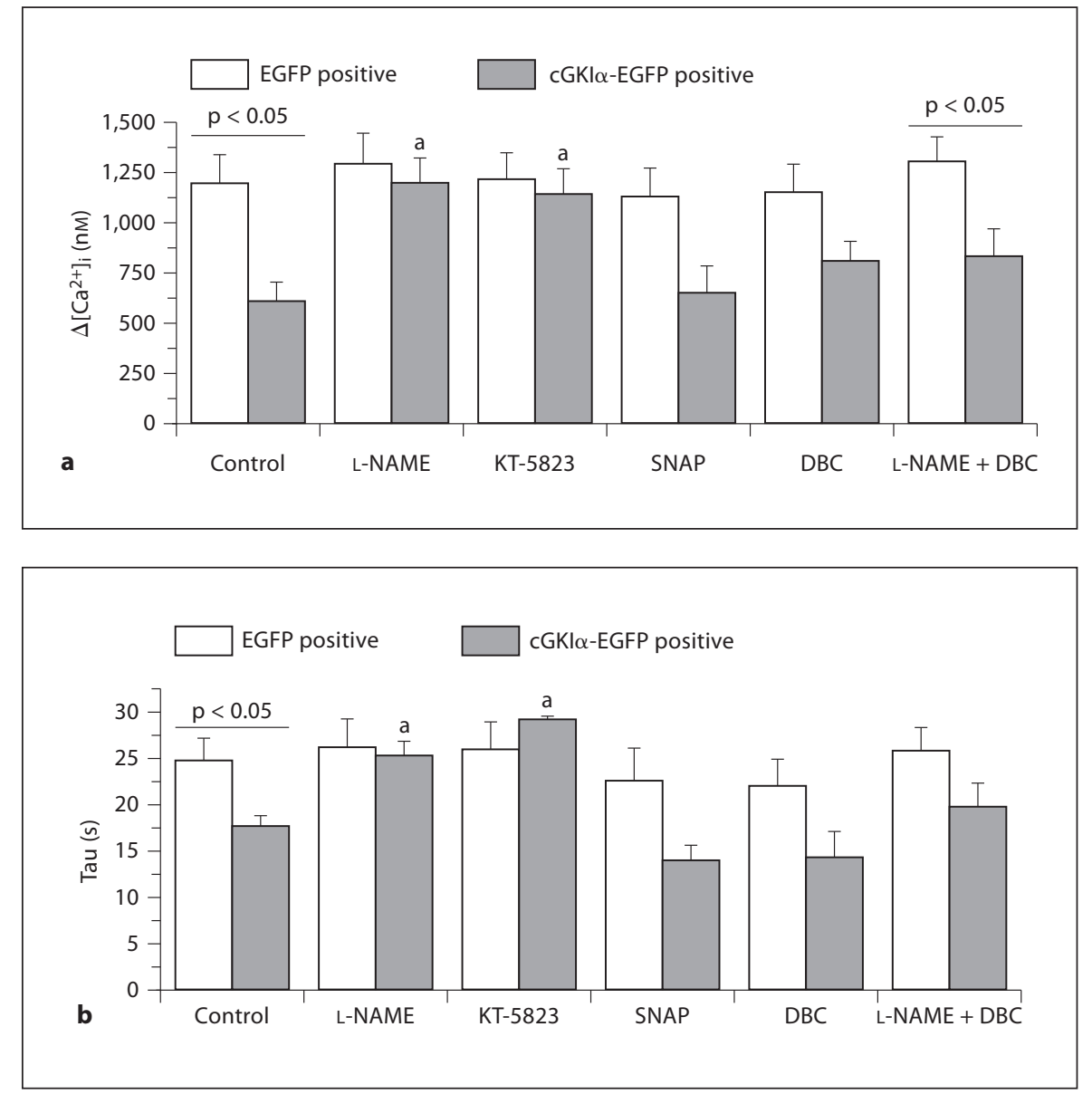

the phosphorylation of phospholamban which, in turn, can increase endoplasmic reticulum calcium ATPase pump turnover. This mechanism may explain the high responsiveness of decay time to the $\mathrm{NO} /$ cyclic GMP/cGKI pathway observed in WKY RCEs. On the contrary, in SHR RCEs (where cGKI expression is low), the $\mathrm{NO} /$ cyclic GMP/cGKI pathway does not modulate $\left[\mathrm{Ca}^{2+}\right]_{\mathrm{i}}$ transient. The low expression of cGKI seems to be a specific feature in the NO/cyclic CMP/cGKI pathway, since eNOS is not reduced in these cells [12], nor is soluble guanylyl cyclase (present data).

In order to test if the low expression of cGKI can account for this difference in calcium parameters, we have transfected cGKI $\alpha$ in SHR RCEs. The re-expression of cGKI $\alpha$ in SHR cells fully restores NO/cyclic GMP/cGKI regulation of the $\left[\mathrm{Ca}^{2+}\right]_{i}$ transient, thus demonstrating that cGKI is the missing step in SHR signaling. In smooth muscle cells isolated from SHR aortas, our research group has already described a similar impairment of $\mathrm{NO} / \mathrm{cGMP} /$
cGKI-mediated calcium handling [10]. It should be noted that, according to the present data, this alteration is not restricted to a single cell type or organ, but may represent a generalized feature.

The consequence of NO/cyclic GMP/cGKI pathway alteration in SHR RCEs could be at least as important as in vascular smooth muscle cells. Indeed, if the inactivity of $\mathrm{NO}$-dependent calcium regulation in SHR vasculature is mainly related to contraction and hypertension, it may imply an over-functionality of eNOS by a reduced inhibitory feedback pathway in RCEs. This pathological NO production leads to toxicity on RCEs (autocrine loop) and cardiac myocytes (paracrine loop) [23]. The cGKI might influence eNOS activity not only by regulating $\left[\mathrm{Ca}^{2+}\right]_{\mathrm{i}}$, but also by direct phosphorylation of eNOS [25]. However, the precise role of cGKI in eNOS activation is still unclear and deserves further investigation [26].

Other pathways can regulate intracellular $\left[\mathrm{Ca}^{2+}\right]_{\mathrm{i}}$ signaling in many cell types. In particular, a complex inter- 
action between cyclic AMP and cyclic GMP through their respective kinases deserves deep investigation. The precise understanding of how these cross-talk mechanisms are regulated and coordinated in endothelial cells is an important direction for future research.

\section{Conclusions}

According to these data, we can hypothesize that in SHR RCEs, a high quantity of biologically inactive $\mathrm{NO}$ is produced, which reacts with other oxygen-reactive species to form peroxynitrite. Peroxynitrite is implicated in heart and vascular dysfunctions through multiple mechanisms including lipid peroxidation, inhibition of mitochondrial respiration, reduction in cardiomyocyte contraction and apoptosis [23]. Therefore, the low expression of cGKI in SHR RCEs may be responsible for cardiac pathologies other than blood pressure regulation.

The role of cGKI in hypertension has been extensively investigated in hypertension and related diseases. Target distruption of the cGKI gene in mice induces a hypertensive phenotype [27]. A reduced mRNA expression of cGKI has been described in aortic rings of 6-week-old SHR [28]. Since at this age SHR are not hypertensive, it could be concluded that a low cGKI expression can contribute to the genetic predisposition of SHR to hypertension. Moreover, both in SHR and in deoxycorticosterone acetate (salt) rats, a mineralocorticoid hypertensive rat model, the increase in aortic cGKI expression induced by hemin is associated with a significant decrease in blood pressure, further suggesting a strict relationship between cGKI and blood pressure [29]. Similarly, in stroke-prone
SHR, the AT-II type 1 receptor antagonist valsartan reduces blood pressure and increases the cGKI expression in mesenteric arteries [30]. However, it remains to be established if the decrease in blood pressure in these hypertensive animal models is the cause or the effect of cGKI protein increase. A different feature has been observed in rats infused for 7 days with AT-II ( $1 \mathrm{mg} / \mathrm{kg} /$ day): blood pressure is dramatically increased, while in aortas, cGKI protein expression remains unchanged [31].

Therefore, the relationship between cGKI and hypertension seems to depend on the pathogenesis of the disease.

Nevertheless, a reduced expression of cGKI has been described in neointimal tissue of patients undergoing coronary angioplasty revascularization [32], suggesting that the enzyme can be downregulated in different pathological conditions. Therefore, further research on cGKI distribution and activity in humans will contribute to a better understanding of cardiovascular diseases and focus on the cGKI gene as a candidate for new gene target therapy.

\section{Acknowledgements}

This work is dedicated to the memory of Prof. Alberto Giotti. The study was supported by grants from the University of Florence.

\section{Disclosure Statement}

No conflicts of interest are declared by the authors.

\section{References}

1 Nilius B, Droogmans G: Ion channels and their functional role in vascular endothelium. Physiol Rev 2001;81:1415-1459.

2 Pueyo ME, Arnal JF, Rami J, Michel JB: Angiotensin II stimulates the production of $\mathrm{NO}$ and peroxynitrite in endothelial cells. Am J Physiol 1998;274:C214-C220.

-3 Bayraktutan U, Ulker S: Effects of angiotensin II on nitric oxide generation in proliferating and quiescent rat coronary microvascular endothelial cells. Hypertens Res 2003;26: $749-757$.

4 Schlossmann J, Desch M: cGK substrates. Handb Exp Pharmacol 2009;191:163-193.

5 Ruth P, Wang G-X, Boekhoff I, May B, Pfeifer A, Penner R, Korth M, Breer H, Hofmann F: Transfected cGMP-dependent protein ki- nase suppresses calcium transients by inhibition of inositol 1,4,5-triphosphate production. Proc Natl Acad Sci USA 1993;90:26232627.

6 Ruth P: Cyclic GMP-dependent protein kinases: understanding in vivo functions by gene targeting. Pharmacol Ther 1999;82: 355-372.

-7 Feil R, Gappa N, Rutz R, Schlossmann J, Rose CR, Konnerth A, Brummer S, Kühbandner S, Hofmann F: Functional reconstitution of vascular smooth muscle cells with cGMPdependent protein kinase I isoforms. Circ Res 2002;90:1080-1086.

$\checkmark 8$ Weber S, Bernhard D, Lukowski R, Weinmeister P, Wörner R, Wegener JW, Valtcheva N, Feil S, Schlossmann J, Hof- mann F, Feil R: Rescue of cGMP kinase I knockout mice by smooth muscle-specific expression of either isozyme. Circ Res 2007; 101:1096-1103.

9 Christensen EN, Mendelsohn ME: Cyclic GMP-dependent protein kinase I alpha inhibits thrombin receptor-mediated calcium mobilization in vascular smooth muscle cells. J Biol Chem 2006;281:8409-8416.

10 Di Cesare Mannelli L, Nistri S, Mazzetti L, Bani D, Feil R, Failli P: Altered nitric oxide calcium responsiveness of aortic smooth muscle cells in spontaneously hypertensive rats depends on low expression of cyclic guanosine monophosphate-dependent protein kinase type I. J Hypertens 2009;27:12581267. 
11 Yao X, Huang Y: From nitric oxide to endothelial cytosolic $\mathrm{Ca}^{2+}$ : a negative feedback control. Trends Pharmacol Sci 2003;24:263266.

$\checkmark 12$ Failli P, Fazzini A, Ruocco C, Mazzetti L, Cecchi E, Giovannelli L, Marra F, Milani S, Giotti A: Lack of nitric oxide- and guanosine $3^{\prime}: 5^{\prime}$-cyclic monophosphate-dependent regulation of $\alpha$-thrombin-induced calcium transient in endothelial cells of spontaneously hypertensive rat hearts. Br J Pharmacol 2000;130:1468-1476.

13 Ecker T, Göbel C, Hullin R, Rettig R, Seitz G, Hofmann F: Decreased cardiac concentration of cGMP kinase in hypertensive animals. An index for cardiac vascularization? Circ Res 1989;65:1361-1369.

- 14 Mazzetti L, Ruocco C, Giovannelli L, Ciuffi M, Franchi-Micheli S, Marra F, Zilletti L, Failli P: Guanosine 3',5'-cyclic monophosphate-dependent pathway alterations in ventricular cardiomyocytes of spontaneously hypertensive rats. Br J Pharmacol 2001;134: 596-602.

15 Failli P, Nistri S, Mazzetti L, Chiappini L, Bani D: Effects of relaxin on vascular smooth muscle and endothelial cells in normotensive and hypertensive rats. Ann NY Acad Sci 2005; 1041:311-313.

16 Pino R, Failli P, Mazzetti L, Buffoni F: Monoamine oxidase and semicarbazide-sensitive amino oxidase activities in isolated cardiomyocytes of spontaneous hypertensive rats. Biochem Mol Med 1997;62:188-196.

$\checkmark 17$ Nistri S, Mazzetti L, Failli P, Bani D: Highyield method for isolation and culture of endothelial cells from rat coronary blood vessels suitable for analysis of intracellular calcium and nitric oxide biosynthetic pathways. Biol Proced Online 2002;4:32-37.
18 Grynkiewicz G, Poenie M, Tsien RY: A new generation of $\mathrm{Ca}^{2+}$ indicators with greatly improved fluorescence properties. J Biol Chem 1985;260:3440-3450.

19 Failli P, Nistri S, Quattrone S, Mazzetti L, Bigazzi M, Bani Sacchi T, Bani D: Relaxin up regulates inducible nitric oxide synthase expression and nitric oxide generation in rat coronary endothelial cells. FASEB J 2002;16: 252-254.

20 Rivero-Vilches FJ, de Frutos S, Saura M, Rodriguez-Puyol D, Rodriguez-Puyol M: Differential relaxing responses to particulate or soluble guanylyl cyclase activation on endothelial cells: a mechanism dependent on PKG-I alpha activation by NO/cGMP. Am J Physiol Cell Physiol 2003;285:C891-C898.

21 Saura M, Zaragoza C, Herranz B, Griera M, Diez-Marqués L, Rodriguez-Puyol D, Rodriguez-Puyol M: Nitric oxide regulates transforming growth factor-beta signaling in endothelial cells. Circ Res 2005;97:1115-1123.

-22 Pacher P, Schulz R, Liaudet L, Szabo C: Nitrosative stress and pharmacological modulation of heart failure. Trends Pharmacol Sci 2005;26:302-310.

23 Pacher P, Beckman JS, Liaudet L: Nitric oxide and peroxynitrite in health and disease. Physiol Rev 2007;87:315-424.

24 Kasseckert SA, Schäfer C, Kluger A, Gligorievski D, Tillmann J, Schlüter K-D, Noll T, Sauer H, Piper HM, Abdallah Y: Stimulation of cGMP signalling protects coronary endothelium against reperfusion-induced intercellular gap formation. Cardiovasc Res 2009;83:381-387.

25 John TA, Ibe BO, Raj JU: Regulation of endothelial nitric oxide synthase: involvement of protein kinase G1 beta, serine 116 phosphorylation and lipid structures. Clin Exp Pharmacol Physiol 2008;35:148-158.
26 Fleming I: Molecular mechanisms underlying the activation of eNOS. Pflugers Arch Eur J Physiol 2010;459:793-806.

27 Pfeifer A, Klatt P, Massberg S, Ny L, Sausbier M, Hirneiß C, Wang G-X, Korth M, Aszódi A, Andersson KE, Krombach F, Mayerhofer A, Ruth P, Fässler R, Hofmann F: Defective smooth muscle regulation in cGMP kinase I-deficient mice. EMBO J 1998; 17:30453051.

28 Ruetten H, Zabel U, Linz W, Schmidt HH: Downregulation of soluble guanylyl cyclase in young and aging spontaneously hypertensive rats. Circ Res 1999;85:534-541.

29 Ndisang JF, Lane N, Jadhav A: Crosstalk between the heme oxygenase system, aldosterone, and phospholipase $\mathrm{C}$ in hypertension. J Hypertens 2008;26:1188-1199.

- 30 Savoia C, Ebrahimian T, He Y, Gratton JP, Schiffrin EL, Touyz RM: Angiotensin II/AT2 receptor-induced vasodilation in strokeprone spontaneously hypertensive rats involves nitric oxide and cGMP-dependent protein kinase. J Hypertens 2006;24:24172422 (erratum published in J Hypertens 2007;25:729).

31 Mollnau H, Wendt M, Szöcs K, Lassègue B, Schulz E, Oelze M, Li HH, Bodenschatz M, August M, Kleschyov AL, Tsilimingas N, Walter U, Förstermann U, Meinertz $T$, Griendling K, Münzel T: Effects of angiotensin II infusion on the expression and function of NAD $(\mathrm{P}) \mathrm{H}$ oxidase and components of nitric oxide/cGMP signaling. Circ Res 2002; 90:E58-E65.

- 32 Anderson PG, Boerth NJ, Liu M, McNamara DB, Cornwell TL, Lincoln TM: Cyclic GMPdependent protein kinase expression in coronary arterial smooth muscle in response to balloon catheter injury. Arterioscler Thromb Vasc Biol 2000;20:2192-2197. 